\title{
Revisioning art and migration
}

Bénédicte Miyamoto and Marie Ruiz

I'm often asked the same question: What in your work comes from your own culture? As if I have a recipe and I can actually isolate the Arab ingredient, the woman ingredient, the Palestinian ingredient. People often expect tidy definitions of otherness, as if identity is something fixed and easily definable. (Antoni and Hatoum, 1998: 54)

\section{Art history and migration studies in dialogue}

How can we rethink art history to uproot its expectations of 'tidy definitions of otherness'? The borders of cultural identity are often drawn according to a 'fiction of authenticity'. ${ }^{1}$ Plural art histories help us challenge the discipline's geographical subfields. They tap into the artistic communities' experiences of 'transcultural or hybrid forms of subject formation and construction of cultural identities, ... the multi-directional processes of migration [affecting] migrating individuals as much as it does the receiving communities' (Chikukwa, 2016: 80). Transnational artistic influences and the migration of artistic communities have long challenged national definitions of identity and heritage. In essence, transnationalism ties international communities through networking and the circulation of ideas between migrants' home countries and receiving lands. Art and Migration: Revisioning the Borders of Community focuses on the conceptual link between art and migration, challenging physical, political and ethnic frontiers, as well as the frontiers of the art community itself - a supposedly globalised community re-assessed in this volume as also structurally bordered by art market dynamics, career constraints and patronage networks for example.

What are the reasons that propel artists into migration and what goals do they pursue? How much does migration impact work and career? What does assimilation, integration and/or multiculturalism mean for artistic encounters and creation? What does art history have to bring to migration studies? These questions highlight the need for an interdisciplinary dialogue between art history and migration studies. Such an exchange helps uncover how 
impactful and manipulative the representations of migration have been and continue to be, offering critical tools to those who study the contours of socalled migration 'crises', their reception and the resulting policies they trigger. In an increasingly international art scene and market, art challenges the structural forces that expound migration as disruptive and that construct the migration experience as an anomaly and impoverishment, when it is in fact a long-standing and fertile human phenomenon. Through its intensifying transnational display and visibility, artistic creation acts as a unifying and global power on our perception of current events, having both the potential to shed light on and overcome physical frontiers and human stigmatisation. Migrations studies increasingly emphasise that 'the cultural construction of citizenship does not take place only within the confines of the policy sphere, but it is also shaped by the continuous re-elaboration of discourse in the public sphere' (Ambrosini et al., 2020: 9) The arts are undoubtedly one of the most powerful discursive structures of the public sphere, actively renegotiating the definition of borders and identity.

In keeping with the objectives of the Rethinking Art Histories series, Art and migration challenges the geographical dividing lines conventionally imposed on art history. It aims to bring to the fore how the myriad trajectories of transnational artworks and artists' careers, far from being marginal phenomena, are the very fabric of the art worlds, sustaining international art centres by the density and dynamism of the networks they create through cross-border movements. If migration has increasingly taken centre stage in contemporary art, this mainly derives from artists claiming the universality of the experience and artistic paradigm of migration - an in-depth re-evaluation that is far more than a reaction to a sense of current 'crisis' (Mathur, 2011). Shifting geographies of artistic encounters are a historical continuum in art, as exemplified by the cyclical relocation of art centres underpinned by migration as well as the waxing and waning of cities' economic attraction and critical mass. This has seen power transfer from Rome and Florence in Italy, to Delft and Antwerp in the Netherlands in the Early Modern period, to the markets and cultural centres of Paris and London in the Modern period. Artworks and artists then transferred from Old Europe to the New World in the Gilded Age. Chinese art saw its attractive power centres shift from court to court, from the city of Chang'an to Luoyang under the Shang to Zhou dynasties, from Bianjing to Li'nan during the Song dynasty, and from Shangdu to Khabaliq under the Yuan dynasty - each move had repercussions on the hybridity and cosmopolitanism of the artistic styles developed.

How did art history explain and analyse these shifts of power and their relation to creativity? It is well documented in art history that after the First World War, some American artists continued to train in France, which had become a destination of choice for artists in the nineteenth century, with 
internationalising art schools (such as the École des Beaux-Arts) and galleries. In turn, these American artists introduced French artists to new artistic forms, and during the Second World War, some French artists fled to New York, which subsequently became a booming art scene attracting a diversity of rich artistic currents and developing the movements of surrealism, expressionism, and abstractionism, among others. In the same vein, in the 1870s, London artists welcomed and supported the integration of many activist artists and Impressionists fleeing the Franco-Prussian war, the Paris siege and the aftermath of the Paris Commune. This also influenced French artists' use of colour, and Monet famously came back at the turn of the century to produce a large collection of London paintings. These interactions between French, British, and American art have long been celebrated with blockbuster exhibitions and museum shows that underline the interplay of artistic influences - but until recently, these Western-centric art histories tended to be narrated with the vagaries of war as contextual background, and rarely with these cross-border experiences as the backbone and catalyst of artistic creation.

Artistic centres in Europe and America have ceded some power in the twenty-first century to more regional locations through globalisation, with the art market allegedly recently experiencing an 'Asian century'. The rise of new markets in the Global South - a term encompassing such diverse country profiles as South America, Africa, India, South-Eastern Asia, and Southern Europe, for example, and used to refer to emerging economies - has disrupted the art market worldwide, also thanks to South-South cross-cultural flows. Increasingly recognised as persistent and specific, the Global South's contribution to the worldwide art market has persuaded art historians to revise how they construed local art as ethnic and embedded in local networks, and international art as highly marketable and universalist, since these labels proved progressively ineffective due to their Western-centric hierarchy. The realisation that the study of art, artists and currents has much to gain from highlighting the inextricable link to migration has sent the discipline of art history itself in a propitious flux: "The "whither" may go hither and thither, but perhaps in the crisscrossing of space and time, art history, though it loses its connecting thread, may gain in its conceptual amplitude', concludes Parul Dave Mukherji in her analysis of the global turn (Mukherji, 2014).

Art and migration acknowledges the cultural relevance of mediating the migrant experience to the world at large. Artworks are semiotic goods, bearers of signs that are perceived in a specific cultural context, and which at the same time disrupt this context. As such, they are both potent revealers and irritants of complex cultural links, of shared beliefs and values (Luhmann, 2000). Historically, even national art schools or academies have somehow questioned national perspectives and values, and canonical art has largely 
been influenced by international artistic heritage. Artworks on migration and discussion of artworks on migration - have increasingly escaped the tropes of exile and have defeated binary analyses that position migrationinspired artworks as the visions of mere in-betweeners and insist on their hyphenated status (Kaplan, 1996). For instance, artists such as Icy and Tot cannot be summed up by the binary label of Iranian-born and Brooklynbased artists - migration has been a recurrent art theme for them, and has arguably contributed to a celebration and inquiry of rootlessness and displacement, their street art mixing, as it does, cultures and languages, on walls in Shanghai or Norway. These artists revision art's histories by challenging our localised understanding of art, and showing us that the artist, 'protean in its adaptative capacity and signif(ying) a subversive force from within any system', mirrors the experience of migrants who 'operate at the thresholds of space and politics language and power and in so doing constantly negotiate and produce new concepts of transcultural identities, both personal and collective, that are destabilising to established orders, systems, and codifications' (Lum, 2020: 140).

Recent curatorial concerns about the visibility of migration in collections and archives are not just reactions to the heightened visual presence of the so-called migration 'crisis' in the media and popular discourse. These concerns tap into a reappraisal of the historic formation of national identities increasingly seen as constructed under international visual influences. Yet, if hybridisation of stylistic references, formats, and subject matters have time and again demonstrated the mediating powers of artistic production, the art world has not yet completely erased the North-South divide. For example, in the case of African and African diaspora artists, 'several factors serve to undermine their visibility; among the mix is the exoticizing taste of gatekeepers of international cultural platforms and the lack of cooperative engagement of concerned bodies inside and outside the continent' (Hassan and Oguibe, 2001: 5). In reaction, museums have taken steps more recently to give centre stage to transnational artistic influences. In 2012, the Tate Britain exhibited Migrations: Journeys into British Art. In 2014 the Smithsonian American Art Museum debuted Our America: The Latino Presence in American Art, an exhibition that toured America. In 2015, the MOMA reunited, for its OneWay Ticket exhibition, the 60 panels of Jacob Lawrence's Migration series, thereby sealing its iconic status in history painting. In 2018, the Kunsthaus Dahlem in Berlin staged New/Old Homeland - Artist's R/emigration, reinvestigating post-war Germany's artistic practice in the light of exile and its connections to international modernity. And the thirteenth edition of Senegal's Dak'Art, one of the most important African art biennials, was inaugurated by the arrival of six artists in a yellow molue - an iconic Lagos bus - having conquered the incessant checkpoints along the South-South migration road 
from Nigeria, Benin, Togo, Ghana and Ivory Coast under the initiative of the Nigerian installation and performance artist Emeka Udemba. By celebrating migration, curators and artists concur that artistic styles and currents are profoundly impacted by migration, and that the will to create is often the origin of migration itself. The Singapore-based Malaysia-born artist Heman Chong's short-term migration to Berlin in 2006 meant 'circulation' and 'the access to a huge pool of people that could either influence or extend your practice', escaping the craft tradition transmitted by Singapore's colonial past, for example (Chong, 2006: 33-35). Experiences vary widely, with artists migrating in search of a better life, of an international career, of more enlightened patrons, or to escape censorship or neo-imperial patterns, but artists' interviews often underline the defining impact of circulation on their work.

As such, Art and migration investigates how movements and exchanges become producers of culture. Art - through the visual materiality of artworks - gives shape and form to the dynamic relationships between artistic communities and both host and home cultures. Art is always a representation of borders, and a commentary on the contours of cultural exchanges, may these artistic encounters be local, regional, or international - and even museums result from these exchanges. Many museums were originally endowed with a historical mission, that of articulating and consolidating a national identity - but they have long been in fact the products of transnational networks of personnel, objects, technologies, and ideas, and are increasingly seen as conduits of diversity, documenting how sedenterisation has rarely been the norm for artists or works of art (Meyer and Savoy, 2014; Whitehead et al., 2017). In successfully bringing together the Dutch and Flemish scene and the English practice of sociability, as in An English Family at Tea (Tate Britain, c. 1720), migrant painter Joseph Van Aken became a successful artistic mediator in Georgian London. So much so that his works, like many of his contemporaries and fellow nationals, have often been attributed to leading British painters (Tate Britain, 2014, 'Collection and Display' \#5: Former Hogarths). Recent vigorous research in art history has emphasised that the worlds of art have historically operated on a transcultural system, which involved migration for training, the reliance on transnational finances and commissions, and intercultural provenance trails (Wrapson et al., 2019). With artists travelling from court to court, and with guilds struggling to repell artists from other cities, while academies fostered training across borders, the art worlds have contended with art crossing borders. Since medieval and pre-modern times, artists have travelled from court to court, crossing the borders of communities, patronage, and polities. Artists, as highly skilled migrants, built upon kinship and merchant networks to gain craft guild membership in host cities and citizenship rights, while academies fostered training across borders (Ojala-Fulwood, 2018). 
Erasure and appropriation are not new phenomena but are still at work in contemporary museums. In their manifesto for curatorial activism, Maura Reilly and Lucy remind us that only 14 percent of the works displayed at MoMA in 2016 were by non-white artists (Reilly and Lippard, 2018). This racism inherent in the display of collections intersects with the lack of representation or even erasure in art history at large of artists who have migrated. British-Ghanaian artist Godfried Donkor's 2001 A Section of Lord Byron's Drawing Rooms, or the 2010 series of 'Self Portrait as a White Man' by the Angolan artist Kiluanji Kia Henda, along with works such as The Great Italian Nude Tryptich or his Merchant of Venice, remind us of the need to reinsert the migrant self into the tableau. These works rewrite contemporary art history by decentring its canonicity in general and its modernism in particular, and highlight the circulation and transfer of art in Europe, which has been migratory for longer than tends to be acknowledged. Amy Lonetree's call to loosen the curators' control over exhibitions dealing with Native American artefacts, culture, and artists resonates with these migrant artists' own demands for selfdetermination in the display space (Lonetree, 2012). Uncovering and reappraising migrations - often silenced by normative archives or by nationalist attribution practices - is part of the workload of revisioning art history and decolonising museums.

\section{Migration terminology: a road map}

If the art worlds have long been terrains of migration, clear benefits are to be reaped from a rapprochement between the discipline of art history and that of migration studies - notably to equip art histories with a terminology that keeps out of political quicksand. Stemming from the Latin verb migrare, meaning to leave or to die, migration refers to a movement resulting in temporary or permanent change of residence. Yet, the terminology generally used to refer to migration today is exemplary of the modern appropriations of the now politically constructed meaning of 'migration'. Has migration - a natural phenomenon that has existed since the dawn of humanity - been turned into an anomaly? Far from unprecedented, migration has marked world history, and understanding that intensified periods of migration have existed before the twenty-first century is necessary to ground current migration patterns in the tradition of human mobility. Yet, an increase in migration flows is sometimes used as justification for popular and political representations of racial and cultural differences, which may explain why the term 'migration' has evolved to somehow become pejorative. Migration flows clearly intensified during the Industrial Revolution, the two World Wars and the decolonisation period. These specific periods triggered tougher control on migration, which framed it as an irregularity affecting the consolidation 
of emerging nation-states, endangering their stability and security. In such contexts, migrants and migration have often become easy targets defined as problematic.

An article published by the $B B C$ news online magazine in 2015, entitled 'The battle over the words used to describe migrants', revealed the general misuses in migration terminology (Ruz, 2015). People indeed often associate migration with the condition of asylum seekers or even refugees, when these are very different terms and realities. Therefore, a road map of the evolution of migration terminology seems necessary. The $\mathrm{BBC}$ article shows how the originally neutral term 'migrant' acquired pejorative connotations, and how it is sometimes mistakenly associated with the negatively perceived term 'asylum-seeker', as if it were synonymous. 'Asylum-seeker' is then incorrectly replaced by 'refugee'. A refugee is a migrant who has been granted refugee status at the end of an often long and difficult process to prove the existence of a danger of persecution in their country of origin and the necessity to seek protection elsewhere. On the contrary, an asylum seeker is seeking refugee status and is waiting for a response to their application. Uninvited and unauthorised, asylum seekers are often deemed unwanted in the receiving country, which may perceive them as economic and social burdens or threats, their integration not yet being given legal status. Hence, these are official terms that are regularly applied inappropriately outside the context in which they were created. Asylum seekers are thus commonly perceived as irregular migrants and are in danger of being deported as non-nationals if refused refugee status. The reason why the term 'migrant' has evolved to be perceived negatively may be explained by its association with the notion of volition, whereas the word 'refugee' is identified with coercion - refugees having no other choice but to leave their home country because of identified dangers and persecution. Yet, some may argue that there is a degree of volition in all migration processes, and this does not prevent 'refugees' being cast as problematic, especially when migration terminologies are inappropriately used. Another such semantic inaccuracy concerns 'economic migrants' who are sometimes associated with asylum seekers accused of migrating with no serious persecution threat, only to enjoy the receiving countries' benefits, whereas the term actually refers to people who migrate to improve their quality of life.

A common understanding of migration terms is necessary to better apprehend the conceptual link between art and migration, as well as the challenges it entails. It is vital for art historians to approach the debate by avoiding imprecise and controversial language, often stemming from widespread misappropriations used in the press. Greussing and Boomgaarden have shown that media descriptions of migrants can generally be split into three representational categories: passive victims, national threats, or dehumanised anonymous. These uses are not without consequences because representing 
migrants as victims may lead to viewing them in desperate need of external support, and thus easily perceived as burdens to the receiving nations. In general, the media describe migrants in a way that suggests societies have no power to regulate the arrival of groups of migrants. The term 'caravan' is a recent case in point. Depicted as threats - generally wrongly associated with crime and terrorism - they can be pictured as dehumanised others, disregarded and rendered invisible (Greussing and Boomgaarden, 2017). Similarly, the misuse of the term 'diaspora', originally referring to the dispersion of the Jews, entails the perception of a disorganised and uncontrolled large-scale group migration, when the word actually refers to communities who maintain links with their home country, in a transnational perspective that fosters socio-cultural bonds. Resorting to a combination of corpus-based approach and critical discourse analysis of British and American liberal and conservative press, Boeva has unveiled the negative stance taken by the media and political actors, as well as their power to shape people's perception of migration as anomalous. She has also revealed that the migrants' countries of origin are an important determinant of anti-immigration discourses, which set the desirable at odds with the undesirable migrants. Boeva has shown that the water imagery regularly used to describe migrant arrivals ('flows', 'stream', 'influx') connotes the uncontrollable nature of population movements and is often associated with perceived high numbers of migrants, in turn inevitably raising popular panic (Boeva, 2016).

Discourses based on fear of foreigners can be fuelled by visual representations of invasion, an example being British pro-Brexit party UKIP's Breaking Point poster during the 2016 Brexit campaign - reminiscent of Nazi antiimmigration visual propaganda. According to Lucassen, many factors have paved the way for the evolution of the definition of 'migration' as a negative term: general dissatisfaction with globalisation since the 1980s, recent terrorist attacks, and the rise of populism have led to the current perception of migration as a threat to national security and stability (Lucassen, 2015). What has also led to the pejorativisation of the term 'migrant' is an obsession with preserving whiteness, a preference for assimilation, and a fear of multiculturalism perceived as a danger to the stability of receiving countries' dominant culture. Restrictive migration legislation has inevitably legitimised the exclusion of newcomers, and has thus fuelled fear of otherness, borderlessness, and social unrest. Today's so-called 'migration crisis' is a crisis of 'otherness' inasmuch as 'others' are perceived as threats coming from outside one's community. This has laden the term 'migrant' with a heritage that is often rejected even when researchers concede that its definitions are operational and descriptions accurate (Sontag, 2018).

On 25 April 2015, during a protest at the European Commission in London, the Movement Against Xenophobia's slogan was 'Migrant Lives 
Matter', echoing the American watchword 'Black Lives Matter', thus openly linking migration to the question of race. According to De Genova, today's 'migrant crisis' is in fact a racial crisis because, despite dominant discourses' racial denial, migrants are often racialised as non-white, a social construct meant to reassert racialised domination and social hierarchies, but above all white supremacy. Blackness is not a question of skin colour, but rather the significant of the construction of hierarchies and power relations (De Genova, 2017a). Fear of immigrants goes hand in hand with questions of assimilation, cultural and ethnic identity, and national borders. The nationstate ideologies, grounded on ethnic and cultural homogeneity, contradict the understanding of migration as a natural phenomenon - borderlessness representing a danger to national homogeneity. Yet, migrating art and artists regularly show that national cultures cannot be understood in isolation but need to be comprehended as transnationally interconnected. In such context, art production and art exhibitions can function as forms of cultural diplomacy against political discourses on racial homogeneity that sustain the structuration of ethnic hierarchies and lead to the perception of migrants as deviant and a danger to the nation-state unity.

This volume proposes an interdisciplinary dialogue between art history and migration studies that highlights art's power to challenge political representations of migration as an anomaly, as well as the ensuing entrenchment of borders between communities. Such interdisciplinary dialogue can be conducted through transnational approaches that underline the parallels between two mobile communities - that of artists and migrants - their mutual understanding, as well as individual and communal bonds. As such, artists and art forms on the move are key actors of cultural mobility. In a dialogue across the boundaries between art history and migration studies, methodological differences are easily reconcilable, the transnational turn being key to developing understanding of migrant communities as well as the art world's mobility and hybridisation. In the same vein, the recent focus on infrastructures of migration - at the meso level between artists/migrants, artworks/non state actors and institutions - also ties in artistic infrastructures, brokerage and migration systems, essential to understanding both art and migration. Against the macro-narrative that regularly frames migration as an anomaly, thus reinforcing the rigidity of national borders, Art and migration challenges the stability of politically constructed frontiers by critically examining art's mediating power to overcome structural boundaries. The objective is also to bring art history to the fore in the debate on how migration is represented and understood.

At the beginning of the twenty-first century, art stands as a resisting force that undermines and reconfigures the intensification of national borders, and this has often meant a subversion and reconfiguration of the traditional 
networks of display, partnerships, and exhibitions. The 'difficulty of matching the gravity of the issue with an appropriate artistic expression ... seemed to disallow exhibition', and entailed a necessity to renegotiate power (Berggren, 2019: 115). In keeping with the contentious nature of their topic, many of these art forms and visual shocks have stood as public critiques of politically constructed borders by also eschewing the traditional presentation spaces reserved for their genre - visuals have been installed in public spaces without authorisation, and documentaries have chosen alternative distribution networks. In 2019 local charities and NGOs and the network Rete Oltre il Ponte set up an unauthorised exhibition of Drowning Hands, a stark visual installed guerrilla-style in the main square of Pescara, Italy, in protest against Italy's Interior Minister Matteo Salvini's anti-immigration policies (see Mezzofiore, 2019). Alejandro González Iñárritu's 2017 VR installation-drama about immigrants, Carne y Arena literally de-centred and disoriented the Cannes festival audience, through its immersive experience set up at Cannes-Mandelieu airport. Similarly, Ai Weiwei sought to disrupt the annual Berlinale film festival in 2016 with his installation of 14,000 life jackets wrapped around the columns of the Konzerthaus in Berlin, a gesture that highlighted his \#safepassage campaign. These controversial and media-savvy moves spark a necessary political dialogue between art and migration, and they generally display viralready iconography, staying rooted in shock - and stock - images of migration and crisis.

Hence, art and migration meet around the notion of border, a major impediment to human mobility, especially at times of political restrictions and border closing. Borders also represent an inspiration for artists engaged with borderlessness and nomadic subjects as the new norm and the future of the artistic community. Their works actively challenge the strict definition of politically controlled borders and restricted human mobility. As such, Moroccan-French artist Bouchra Khalili explores the ambiguities of borders as limitations and opportunities by exhibiting minorities performing their resistance narratives and strategies against structural powers. Mostly working with installation, print, video, and photography, she represents the multifaceted dimension of migration infrastructures - both negatively inhibiting and positively enabling mobility. She thus uses individual experiences to represent collective stories that envisage borderless communal structures, as in her series of videos The Mapping Journey Project (2008-2011) and the Constellations Series (2011).

This volume agrees that art history cannot be 'independent of the history of exile, migration and economic exchange', and that 'the local has always been irradiated, as it were, by the larger world' (Greenblatt, 2010: 3-4). However, it argues that the term 'cultural mobility' is understated and indirect, thus rendering it ineffective. The book advocates instead for a wider use of the 
unromanticised and politically unambiguous term 'migration' in art historical narratives. If 'cultural mobility' has been increasingly adopted by art historians, it is because it is a useful term to also discuss the flow of materials, artefacts, and techniques through human mediation (Tilley, 2001; Knappett, 2005). In order for art history's gaze to remain firmly fixed on the agent-provocateurs behind the flow of objects, ideas, currents, and avant-gardes, a shift in terminology needs to be favoured. The term 'migrant', 'with allowances for voluntary movement and self-willed acts of mutability and becoming' (Demos, 2017: 18) should be favoured since it implies cultural mobility without being bottled up by it. Reclaiming the term 'migration' will help us explain why the term has become subjected to judgement, and found guilty of 'desertion [that] amounts to transgression' compared, for example, to the term 'diaspora' (Guha, 1998). And, in turn, art history should engage a reflection on the strict accuracy of terms such as 'bohemian', 'itinerant', 'peripatetic', 'nomadic', 'exiled', and 'refugee'. These labels are linked to a category of reasons - supposedly discernible, measurable and autonomous - why the person migrated, and they are employed in ways that often overstretch even their precise periodical, political, sociological, and cultural definitions (Bruneau, 2010; Hicks and Mallet, 2019: 47-65). Contrary to Anne Ring Petersen, we vouch that analytical precision necessitates the term 'migrant' to be used more systematically, precisely because we must put rest to the idea that definitions are only operative if they gauge how 'voluntary' or 'self-willed' the act of migration is, has been or will continue to be (Petersen, 2017: 6).

\section{Art and borders}

Recent studies of art crossing borders have evidenced that the supposed fixity of national identities was actually an intellectual construct elaborated in reaction and in parallel to the tightening of cross-border informational networks, the increase in market integration, and the international expansion of careers - and that this phenomenon, which was full blown in the nineteenth century, started as soon as the Early Modern era (Baetens and Lyna, 2019). The nation-state ideal that emerged in the Modern era has entrenched politically constructed borders by defining national identities as key and uniform, thus excluding undesirable non-nationals as threats to national homogeneity. Yet, art has constantly used non-national models as sources of inspiration and fascination, choosing its models and visual references from cultures beyond its perimeters, and contradicting the nation-state ideal of racial and cultural homogeneity. The Smithsonian American Art Museum's symposium 'A Line that Birds cannot See': Mexican/US Arts and Artists Crossing Borders in the 2oth Century (November 2018) derived its title from Alberto Ríos' poem The Border: A Double Sonnet (2015) to underline the soft power of the arts, 
and how it can influence public opinion on migration against the polarisation induced by politically constructed borders:

The border is a line that birds cannot see.

... The border is the blood clot in the river's vein.

The border says stop to the wind, but the wind speaks another language, and keeps going.

... The border is a big, neat, clean, clear black line on a map that does not exist.

Comprehension of population movements has been affected by the standardisation and the literal 'bad press' of repetitive and harrowing displays of migrant visuals, filmed and photographed according to ethnographic and quasi 'war zone' documentary style. This has impoverished the debate on art and migration and obscured the historical continuum of so-called migration 'crises'. The foregrounding of the plight of the migrant has led to many artistic reactions, creations, and events that have set their goal on raising awareness by relying on the shock experience and powerful mediation of artworks. The portmanteau word 'artivism' joins 'art' and 'activism' to categorise art that primarily intends to push a political agenda or a social message. Artivist artists have been confronted with the difficulty of establishing an artistic dialogue with the stereotypical migrant visuals, and yet meeting the goals of triggering empathy as well as shame in the audience. These issues are at the heart of the recent development of cross-cultural visual politics (Danko, 2018). Dutch artist Lonnie Van Brummelen's 2004-2005 triptych film entitled Grossraum (Borders of Europe) is a reflection on the current public concern for migration and the states' 'tactics of bordering' (Anzaldúa, 2007; De Genova, 2017b). She chose to represent border crossings from 'a high point of view at an appropriate distance from the frontier post, so that individual persons cannot be recognised' - a choice that was led by the necessity to comply with security regulations in a UN-controlled territory where even photography is forbidden without permission, and the subverting irony of choosing to present silent travellings in grainy Agfa colours on $35 \mathrm{~mm}$ film, thus smacking of surveillance films. The artwork operates fully with its appended 40-page dossier 'Formal Trajectory' documenting her arduous application process for official authorisation. It professes multiple times, for example - tongue firmly in cheek - that 'any possible misunderstanding of the Green Line as an official border will not occur' (Van Brummelen, 2005), and provides a clear parallel with the migrants' daily encounter with the absurd administrative labyrinth. However, there has also been increasing interrogation within the artistic community about the efficacy of representing the migrants' plight, given the exploitative pitfalls of the subject matter, in the context 'of an emergent politics of documentation and the counter-politics of witnessing' (Hicks and Mallet, 2019: 20). Questions have repetitively arisen over the moral 
acceptability, and the limits of art's ethical responsibility when the audience is faced with art installations of salvaged migrant objects - from the recurring trope of migrant shoes to the 2019 Barca Nostra exhibit of a shipwrecked migrant ship at the 58th Venice Biennale. ${ }^{2}$ Critics have also questioned the methodological blind spots of video art that choose poor quality image and sound, or unedited and extensive footages pretending to document as close as possible the reality of a life 'on the move', as if unmediated documentation was a possibility and as if visual samples could in any way become generalised (Yanow, 2014).

Questions have also arisen over the potentially harmful choice of offering visually stunning images in noble, extensive, and canonical materials - such as Rebeca Belmore's 2017 marble tent Biinjiya'iing Onji (From Inside) created for Documenta 14 in Athens - thus rendering scenes of suffering beautiful (Demos, 2013b; Ong, 2017). The theme of migration places these works of art at the centre of a turmoil of questions and current disputes on visual politics and the ethics of representation. Emma Chubb, Smith College Museum of Art's curator, underlines that too often representation of migration 'rely on visible markers of racial, linguistic, and geographic difference in ways that recall earlier Orientalist and colonialist representations of the "Other" (Chubb, 2015: 268). She questions 'to what extent does art reproduce exotic scenes of subjection, already so ubiquitous in European media outlets, for the pleasure of the art tourist and the cultural capital of the exhibiting museum, gallery, or organization?' (Chubb, 2016: 30). The many intersections between artistic experimentations with current issues and problematic responses to migration viewed as an anomaly provide fertile ground to explore both aestheticism and the flirting with visual media stereotypes that is often at the heart of artivism - itself over-determined by a sense of urgency. This has often elicited artistic responses solely focused on non-Western, South-North, and Mediterranean migration, and wrapped up in documenting emergency. Artistic reactions to the phenomenon of migration have also deepened reflections about the transformative power of the arts in the face of current events described as crises, and ultimately, this has opened up crucial discussions on how, for what and for whom art works. The growing endeavour of artists to claim art as a social consciousness trigger has been one of the most important discussions accompanying the museum and art scene's turns from art as canonicity and authority, to art as education and documentation, and more recently to art as empathy and counter-witnessing (Demos, 2015; Hicks and Mallet, 2019). In this process, art on migration or by migrant artists has been a catalyst for these deconstructions, making for a 'catalogue of other places, moments, and a constellation of dispossession in the world ... a critique of the structure of feeling that Said has referred to as the "quasi-religious authority of being at home among one's people"' (Said, 1983: 16; Mufti, 2011: 193). 
How can art mediate the experience of dislocation and movement by creating images of migration that revitalise the gaze of the audience? The concept of migration in artistic practice is increasingly viewed as challenging frontiers, as creator of in-between and uncertain spaces where multiple contexts, places and times encounter and contradict the fixity of state-controlled structures. The topics these practices tackle have widened the dialogue in a way that narratives centred on the voyage have not. The latter have latched on a point in time, and are influenced by the fallacy of the term 'crisis'. They represent migration by locating its 'decisive point' - a synonym for 'crisis' in the act of passage. But more rounded representations of migration also broach topics of memory, loss and grieving, resettlement and translocation, immobility and state of limbo, and the trauma of hybridised, violated, and estranged identities. For instance, UK-born of West Indian descent Hurvin Anderson's Jersey (Tate Gallery, London) represents the interior of a barbershop in Kingsland, Jamaica. Anderson's work exemplifies the notion of in-betweenness and documents the post-war arrival of Caribbean migrants in the UK as well as the interplay of transnationalism and assimilation. Allying photo-realistically depicted objects and the incongruity of brightly coloured squares and implausible shadows dispersed in the picture as floating elements, it plays on absence and presence, and the blurring of memory - a testimony to the in-betweenness of the migrant. It reflects the triangular socio-cultural relationship between the welcoming and sending societies and the in-between spaces where second-generation migrants create their lives. Far from being solely limited to disrupted identities, in-betweenness is also a creator of hyphenated identities, a space of exchange where practices and references hybridise. Expressing diverse experiences of culture and identity, as well as the intersecting importance of migration and racialisation, Anderson's work is diasporic. It reflects a sense of in-between and a lasting discrepancy between migrants' self at departure and their adjustment to their new home - in pictures where figures are often absent, or at best turning their back on the audience. The migrant's struggle for public and political visibility is the central question in these images, and their ontological struggle lies in the 'capacity to appear' (Rancière, 2003). It is noteworthy that the notion of home has been challenged as an unstable notion by recent scholarship in migration and border studies, and the term of in-betweenness has the merit of highlighting the emotional toll for migrants - who struggle to reach the 'final destination of their geographical and moral journey' (Belloni, 2019) - that often also translates into the political and social burden of being treated as a labour pawn rather than a citizen.

The 'national situation', as Fredric Jameson reminds us, is for many artists an inescapable situation and depends neither on ideology or choices, since 'the continued existence of nation-states is tied to labor ... [artists] 
work in that, and what they can do they do in that. What they can't do is dictated in that. It's a boundary that cannot really be transgressed' (Jameson, 2010: 14). The setting up of the migrant as a reference image of cross-border universalism is part of the resistance to analysis of art in terms of 'culturalism' and national specificities, but in some cases it can also miss the point. It can distort the reality of the migrant experience in both the home and host countries in favour of a supposed state of mobility that for many is only episodic, rarely disconnected, and even more rarely freeing from labour constraints. Although art - as this volume underlines - is by essence a questioning and transgression of borders, the flow across borders of art - and even more so of artists - remains difficult and significantly hampered by national barriers and state lines. The redistribution of power between centres and peripheries thanks to the migration of art and artists, if not a recent phenomenon, is still also far from prevailing yet (Velthuis and Baia Curioni, 2015).

\section{Migration and global art worlds}

Art and migration underlines the linkage between migration and art as a long standing, rather than new, phenomenon with regional and transnational perspectives. Art history of geographically defined areas is now rarely conducted as an essentially national project framed by the space of the nation-state, and comparisons between international contexts and transnational contacts are not marginal anymore, but are analysed as defining and integrated causalities, with artistic exchanges firmly placed as the root of stylistic developments for example. As historian of migration Dirk Hoerder notes, 'the customary way of approaching the world's vast territorial expanses has been the division into continents, clearly bordered and named entities. However, in the last decades scholarship has become critical of "borderlines" and for almost a century has been critical of "place" (Hoerder, 2019: 22). Hoerder contends that geographical fixity restricts analyses of migrations to established terminologies and prevents human conceptualisations. He also suggests that dividing physical geography into macro-regions of human connectedness is more efficient, as macro-regions take into account physical resources and human activity. According to him, 'research requires an inclusive and analytical historical narrative as a basis for socialization into ways of thinking about migrations' (Hoerder, 2019: 35).

Studies in the globalisation of the art worlds have not erased borders by opting for a study through the lens of world economy. Rather, they have reinforced the analysis of the subnational phenomenon of global cities, and enhanced attention to their transnational (rather than international) coordination of vibrant and denationalising networks (Sassen, 2006). In the art world, this decrease of inter-state power and national framings has been 
relayed through city branding and organised fairs and biennials. Yet, curatorial autonomy and progressive and/or radical political messages are often at odds in these major, money-making and highly staged fairs, biennials and exhibitions, which tend to be held in conventional venues that have a long history of institutional shows of power (Jones, 2016). Critics of these events and of the attractive power of global art centres show that the global 'turn' is not so much a global momentum as an overreach of market forces, and that global nodes reproduce a colonial model of synergy and authority between the centre and the peripheries (Quemin, 2004). Critics also often underline that both Western art historical practices and Western art market networks are not as far-reaching and all-encompassing as the term 'global' would convey, and that both local biases as well as literally off-centre art historical practices thrive in other parts of the globe (Chakrabarty, 2000; Vermeylen, 2015). Refusing to reinforce state borders, questioning how colonial practices are reproduced in fairs, and generally reappraising how much movement, porosity and interstitiality actually animates the art worlds have become pressing questions for art historians, curators and practitioners. Already in 2010, the imperative was pressed upon art historians: 'Since so much of the art market and international art practices have to do with global travel, global art display, and global markets, [we need to see] what kinds of inclusions and exclusions are at stake there' (Valiavicharska, 2010: 6). Country specific exhibition pavilions, for example, used to be the defining architecture that sustained and fed national artistic narratives. The 57th Venice Art Biennale exploded these constructs in 2017 by rebranding them as 'trans-pavilions' in its Viva Arte Viva Core Exhibition at Arsenale, and organising the biennials according to flux and themes (Macel, 2017). These are more than just label changes or the sign of shifting territories in art historical disciplines. Discussing the broader dialogue between art and other international borders initiated by the 1984 Border Art Workshop / Taller de Arte Fronterizo (BAW/TAF), Ila Nicole Sheren concludes:

There is enormous potential in thinking of art in terms of change rather than as objects. Even when socially motivated artists generate an aesthetic product such as ... Téllez's cannonball [One Flew over the Void (Bala Perdida), 2005 ${ }^{3}$ ] the object is only part of the whole. It is not that the physical product ceases to matter, but that it coexists with the post-autonomous. (Sheren, 2015: 135)

Revitalising the theme of borders in art leads to the reorganising of (display) space, to a questioning of the self referentiality of art and, as a political discourse, it leads to examining colonisation and the effects of globalisation in art practices. In a post autonomous thinking and practice, art has a potential for change, since its role is mediation, and the physicality of the art object is just one stage - the trigger - in developing art that is completed 
in the audience's reception, experience and re-action. The focus on art 'on the move' has also led, however, to juxtapositions that have been accused of being disingenuous at best or offering only lip service to the 'global turn'. In Contemporary Art and the Cosmopolitan Imagination, Marsha Meskimmon reminds us that the increased 'passage' of art originating in migration does not mean that the imperialist structures (which after all rest on increased circulation of goods) do not impact the interpretation or distort the meaning and discipline the reception of that art (Meskimmon, 2011). These controversies have shaken many a biennial and an exhibition, from the universalist attempts of the Magiciens de la Terre 1989 Pompidou Center exhibition to the globalised artivism of the 2017 Documenta 14, which attempted to decentralise by holding its exhibitions both at the recurring host-city of Kassel as well as in Athens (Bydler, 2004; Green and Gardner, 2016; Floyd, 2017). It is in this chaotic field that Art and migration wants to resituate the phenomenon of migration and reappraise the term itself. Connecting art to conflict zones and burning issues, the curator of Documenta 14 Adam Szymczyk intended to show that 'the contradictions of the contemporary world, embodied by loaded directionals like East and West, North and South, meet and clash' (Szymczyk, 2015) and are necessary to decolonise the art scene. But the determination to "insist on the importance of "trans" thought ... as an opportune way of referring to the circulations-translations-displacements-exchanges between different countries, cultures, persons and artworks' (Dulguerova, 2017: 2) has sometimes transformed the themes of migration into an uncritical catchall, while at the same time paradoxically trying to praise and normalise the phenomenon of migration by erasing the term.

The shift in focus initiated by the 'global turn' has made especially clear that global node cities can only be recognised as 'art worlds' if these cities can be defined as 'extended' - meaning that they rely on cross-border networks and provide avant-garde movement (While, 2003: 252). This has also driven home the realisation that the phenomenon of migration in art is far from recent, and that there is a pressing need for a historical perspective to further investigate how these centres have wielded power over the peripheries, and how they have organised the cultural and economic flow. The global art world has often been portrayed as a liberation of national borders but we hope this volume will further open up new ways of criticising the enduring power of global node art scenes. Their structural power over creation, access and careers needs to be reassessed in a historical continuum that highlights the colonial roots of globalisation (King, 1990), and which underlines that ultimately, these nodes are and have been heavily dependent on transnational movements of artworks and artists. Furthermore, not only has migration become a focus of contemporary curatorship, but migration has affected the support network of the art market itself. 


\section{State of the art}

Influenced by the surge of the migration turn in the 1990s, social and political scientists as well as historians have growingly challenged territorialism and localism in order to chart in-, out- and internal migration and the societal impacts of population movements in general. Major works on migration include Dirk Hoerder's study of individual and group systems of migration, Donna Gabaccia's work on constructed migrant identities, Marlou Shrover's deconstruction of categories of migrants as well as geographical interdependences in globalised contexts, Leo Luccassen's analysis of global migration history and migration systems, and Eric Richards's methodology engaging a dialogue between micro and macro experiences of human mobility. Since the turn of the twenty-first century and even more so in the past decade, many works on migration have tended to deconstruct the so-called 'crises' of migration by focusing on how structural forces portray migration as problematic, and these generally fall within three main themes: how the media frame migration as an anomaly (see Hier and Greenberg, 2002; Cisneros, 2008; An and Gower, 2009; Georgiou, 2012; Van der Meer et al., 2014; Holmes and Castañeda, 2016); the political structures' contribution to cast migration as an anomaly (see Boin, 2004; Boin et al., 2009; Mainwaring, 2012; McAdam, 2014; Lindley, 2014); and finally a focus on human rights and NGO's involvement in defining migrants as passive victims and consequently migration as disruptive (see Weiner, 1995; Tacoli, 2009; Schuetze, 2015).

Art historians have recently explored the interplay between art and migration, whereas this is rarely the case in migration studies, with exceptions to be found in the present volume with Tazreiter and Lewis, both migration scholars who are focusing on the connections between art and migration in this volume. Art history studies of migration generally fall within the following categories: the first one focuses on transnational approaches of cross-culturalism with specific case studies of migrant artists' communities and their international networks (see Mercer, 2008; Mathur, 2011; Waller and Carter, 2015; Wagner and Klemenčič, 2017). The second category brings to the fore questions of aesthetics, culture, and memory (see Del Guidice, 2014; Mosland et al., 2015). Finally, a political exploration of the interplay between art and migration has also been proposed by art historians (see DiMaggio and Fernandez-Kelly, 2010; Cooks, 2011; Demos, 2013a). The major lacuna that this literature review reveals is the limited presence of art history works by migration scholars. One such exception is John MacKenzie's work on colonial museums and orientalism (MacKenzie, 1995; 2009).

Studies of migration are wide ranging as far as chronologies, intersecting disciplines, and methodologies are concerned. Yet, although transdisciplinarity has been successfully promoted by established scholars such as Hoerder, 
Schrover, and Lucassen, research on migration has mostly been limited to specific disciplines, geographical and social contexts as well as specific time spans. Since the publication of the pioneer work by Leslie Page Moch in 1992 - Moving Europeans: Migration in Western Europe since 1650 - a growing body of work has challenged fixed chronological borders and taken long views proving that migration phenomena are long-lasting features of societies (Canny, 1994; Fauri, 2015). Yet, until very recently, migration studies and art studies functioned as two different spheres and little attempt has been made by scholars to reconcile methodological differences, so the involvement of migration scholars in art studies has remained limited.

This volume identifies three critical points in the state of the art. First, traditional art studies focusing on national borders - since challenged by transnational approaches - have long excluded cross-cultural interactions. At the same time, they have created an artificial dichotomy between domestic and international arts. Less attention has been paid to the political construction of borders, and the art world's soft power has been mostly excluded by migration scholars. However, this volume adopts a borderless approach and shows art's power to overcome politically constructed borders. Second, a scientific dialogue between the artistic scholarship and migration studies is being engaged mostly by art historians, challenging the fixed boundaries between those two fields' methodologies and going beyond the limited scope of cross-culturalism. A survey of the literature on art and migration clearly shows a focus on contemporary situations, yet art has long informed and challenged the essential role of migration in past societies too. The phenomenon of migration has been primarily examined through the prism of its current economic, social, political, or security implications, and the cultural inferences have only been addressed very recently. Third, artists and the art world have been influenced and inspired by migration, yet the art world's artivism and involvement in socio-political debates have mainly been overlooked, to favour a focus on aesthetics. This volume addresses those gaps by taking micro- and macro-level analyses to show the artificiality of fixed borders in local as well as global perspectives. The book also includes a wide range of actors, situations, and locations, with chapters focusing on art's borderlessness. It thus bridges the gap between national and international art in a transnational perspective, and shows the fecund interaction between art and migration studies. To deal with the paucity of transdisciplinary studies of art and migration, it is necessary to show how the art world questions the consolidation of national identities and borders.

The chapters in Art and migration reveal that, although the sheer scale of migration movement might be a current concern, art has long been critically addressing statelessness and cross-border experiences, and its market was early on an international one. Art and migration is not confined to one 
single form of art, but includes a variety of art forms that inform migratory influences in the arts in general. The historical disruption of borders by art makes it crucial to assess and compare the different long-standing artistic strategies to mediate experiences of migration, making them familiar, empathetic, and legitimate, and countering the politically motivated images of the migrant tooled as a dehumanised other and alien. For instance, Mona Nicole Sfeir's Pinpoint - exhibited in Washington DC in 2016 - relies on the imagery of stars once used by navigators to find their way across the oceans to draw attention to forced migrants' hopes. Another case in point is the Tate Modern's exhibition Hyundai Commission: Tania Bruguera (October 2018February 2019), grounded on 'forced empathy' to raise awareness of the global migration 'crisis'.

Hence, this book deals with a controversial and crucial theme, and covers significant case studies on the linkage between art and migration. Mirroring the connection of statelessness between art and migration, it includes the study of a variety of ethnic groups and geographical areas as well as in-, out- and internal migrations. It combines newly published chapters on the production and circulation of artists and artworks and is neither limited in time nor in geographic scope, but rather reflects the globalised links between art and migration, art's inclusive power, and experiences of exclusion (individual and group experiences). As such, it offers a dialectical approach to the relationship between art and migration.

Long-standing artistic mobility has led to the increasing hybridisation of art and culture, a cross-pollination that is essential to the vitality of culture. Challenging the binary opposition between spaces of departure and arrival, Anderson's conception of 'diasporic imaginary' intersects the notions of transnationalism and nationalism (Anderson, 1991). Today, 'global imaginary' and 'national imaginary' combine around the acceptation of shared global ideologies of a nation (Steger, 2008) and multiple belongings, rethinking the concept of diaspora in terms of hybridity. We still need more comparative study of how nations and territories approach the shared issues of regional or global significance in the arts - and how artistic encounters 'on the move' are far more than simple centre-periphery dynamics. Furthermore, if art has the power to defy territorial entities defined by their physical or politically constructed borders, the study of migrant artists and artworks also reveals the existence of socio-spatial and socio-cultural borders in the art world. Indeed, collaboration strategies, the presence of gatekeepers and the issues of access to the art scene often results from intense and opaque filtering processes, or the contours of communities of interests, artists' collectives and inter-regional connections through workshops or schools (Chang, 2009). Structural borders exist in the art world itself and have to be highlighted, given that migration studies remind us on the one hand that controls on migration movement have 
been imposed on all but a wealthy elite and, on the other hand, that art market studies emphasise the extant inequality and wage disparity on the art scene. Globalisation is a largely unequal process. Any study of art and migration has to emphasise the interconnected networks and the borders that forge the artists' migration routes, as well as the many liminal spaces between recognition and exclusion that make or break a migrant artist's career.

\section{Organisation of the book}

The chapters included in this volume offer a wide range of responses and theoretical approaches to account for the fruitful relationship between art and migration. They all commonly investigate the very existence of borders and art's power to mediate migration experiences. As such, Art and migration challenges the dichotomy between migrant and non-migrant art and questions the oppositions between individual experience and group knowledge of migration. It presents migration as decidedly fragmentary - a class-ridden, gendered, and racialised experience - but also as informing group comprehension and cultural values. It delineates how memory and experience of migration shape the present artistic culture and challenge the notion of national identities in a globalised context.

The book is divided into three parts, each beginning with interviews of artists and curators inspired by migration. These are precious additions to the academic chapters that shape the volume as they offer tangible perspectives on the interrelation between art and migration at the time of writing. In giving a voice to people who are not academics - a voice to the stakeholders and mobilisers of the art community - we are making what we believe to be an ethical choice. We consider including these voices as necessary when assessing and criticising the notion of 'art community'. These interviews inform the study of identity politics and vividly account for the challenges of working in the art world. They are not just secondary illustrations of the interplay between art and migration in the art world, but are significant testimonies from actors and actresses of the interaction between migration studies and art history; they are accounts of lived experiences by witnesses and stakeholders of art and migration. They authentificate the fruitful relationship between the art world and the phenomenon of migration, and they demonstrate that both art and migration inform each other and are interdependent. What we glean from these interviews is that the role of artists in hot debates and politicial issues is one marked by in-betweeness - sometimes an uncomfortable place for witnesses with the power to show, insinuate and illustrate current scandals, yet with a wish to take a back-seat and not to overtly influence viewers. What we also learn from these interviews is that curators face a variety of constraints from national, non-national, 
international and global structures - realpolitik - when dealing with politically laden themes. The interviewees all concur that art challenges politically constructed borders, that artists are mobile, and that such trends partake in the redefinition of the 'national'.

Starting with the interplay between art, migration and the notion of border, the first section reveals the artistic power of migration and exposes how both sending and receiving countries have nourished artistic creations, whether through idealisation or deprecation. The hybridisation of artistic influences is central in this part, which also explores the links between art and diasporic aesthetics, and discusses how cultural exposure and artistic migration mirror geopolitical engagements and economic relationships. The first part of the book opens with an inverview with Dieter Roelstraete, curator at the Neubauer Collegium for Culture and Society at the University of Chicago, on the contemporary art exhibition Documenta 14 (Athens, 2017). Among other topics, he describes his collaboration with German artist Olaf Holzapfel on an installation entitled Zaun ('Fence'), which questioned the inbetweenness of borders - paradoxical generators of both constraints and possibilities. This is followed by an interview with American artist David Antonio Cruz on his Chocolate Series created between 2011 and 2015 in response to the framing of migrants as threats, and which largely featured in the Smithsonian National Portrait Gallery Portraiture Now: Staging the Self exhibition that toured the United States from 2014 to 2016. He describes how the Chocolate Series exemplifies his artivism and was created in reaction to anti-immigration policies in America. This is followed by an interview with Swedish artist Axel Karlsson Rixon, whose exhibition at the Musée des Beaux-Arts in Rouen, France, was entitled Mobilité Mémorable. They describe how they were inspired by Évariste-Vital Luminais's Les Énervés de Jumièges, as well as by a visit to the infamous migrant camp sadly called the 'Jungle of Calais', and their exploration of the migration history of the Normandy region.

The first academic chapter of Art and migration is Birgit Mersmann's study of the diasporisation of the Chinese art scene. This transnational perspective of migration and diaspora is grounded in the case study of two Chinese artists who migrated to Australia - Ah Xian and Dong Wang Fan - and who exemplify the construction of diasporic aesthetics and Chineseness in Australia. This is followed by Christopher T. Green's study of North American Indigenous art exhibitions both retracing and challenging colonial and imperialist history. Green grounds his work in Indigenous art at international biennials and transmotive geometries to unveil underlying deimperialising gestures. This analysis ties in with Claudia Tazreiter's examination of the persistence of colonial imagery, racialisation, and artists' power to tell the stories of silenced and invisible migrants. She evokes the prickly situation of Australia's detention camps, and brings to the fore the art world's intervention and impact on 
such remarkable political and social issues. This political science approach to the interconnection between art and migration is further enhanced by Rachel Lewis's chapter on female refugees and asylum seekers, which examines politics, art and migration through the prism of participatory arts projects in the United Kingdom and the timely concepts of deportability and temporality.

What binds the chapters of the first part of Art and migration together is the display of art's discursive power, with many artists' political activism often intimately affected by the recent so-called 'crises'. Indeed, art creates a space to contest anti-migration campaigns as well as the structural forces that generate migration 'crises'. Art has an undeniable educational mission because visual representations of migration have the power to influence public opinion on migrants, and to popularise migration experiences. The notions of mobility and activism are significant in this section, which unveils the power of art in worldwide political issues as well as its contribution to shaping global visions of migration. As such, while art history has increasingly been written transnationally, it continues to mix national and homogenised ethnic labels, reproducing an asymmetrical power relation. This leads to an examination of gender and race in the arts through the scope of national and transnational values.

The second part of the book focuses on the migrants' paths in the arts. The level of integration of the artists in their home and settling countries is assessed by case studies of their career, their reception, and recognition. The perception of their identities are often paradoxical in both countries. The thorny question of how artistic production is measured, defined, and used by proponents or opponents of integration is also of interest here. Art and museum structures (collectors, galleries, and subsidising networks) generally trigger cultural re-evaluation and cultural resistance to assimilation by focusing their exhibitions on contemporary concerns. Media coverage may also affect the frequency of cultural events as well as the labelling of artistic groups. Cultural connectivity, cross-cultural engagement and the circulation of knowledge are exemplified by new cultural networks and the internationalisation of the art market. As such, court, diplomatic, religious or political networks - which may influence the migration of art and artists - are key, along with the existence of unions, guilds, cultural centres, or prizes and artist-in-residence programmes. Private patronage and public support partake in the celebration of roots and identity - delineating a past history in the sending country - but are also acts that take pride in social mobility, empowerment and success - boasting a host country experience.

This section opens with an interview with Marina Galvani, art curator of the World Bank art collection, focusing on the exhibition Uprooted: The Resilience of Refugees, Displaced People and Host Communities (November 2017-November 2018), which showcased artists - some of whom were refugees themselves - dealing with migration and the impact of transience on 
individual lives and entire communities of people. Galvani engages in a discussion on the World Bank's Art Program and the constraints of curating activist exhibitions in the face of political turmoil. This is followed by an interview with Robyn Asleson, assistant curator in the Department of Prints, Drawings and Media Arts at the National Portrait Gallery in Washington, and curator of Portraits of the World: Switzerland (December 2017-November 2018), who talks about the nation-building narrative and transnationalism of American art, with a specific focus on cultural exchanges with Switzerland. She also evokes the notion of global feminism and institutional aspects of curatorship. Then comes an interview with artistic director of the New Museum, New York, Massimiliano Gioni, who curated the Phillips Collection's The Warmth of Other Suns: Stories of Global Displacement exhibition (22 June-22 September 2019, Washington, DC). Gioni reflects on his personal experience of migration as an Italian-born migrant to the United States. He mentions the political influence of the media and governments in generating dramatic scenes of migration, especially across the Mediterranean Sea, as well as the art world's responsibility in documenting history in the making.

Aimé Lukin's chapter focuses on the New York art scene in the 1960s-1970s and the integration of artists of Latin American origin. She examines the impact of a dual North-South cultural origin, as well as institutional influences and the art market. She also accounts for the participation of artists of Latin American origin in avant-garde movements and how they redefined stigmatised perceptions of Latin American art in the United States. She bases her study on Contrabienal (1971) and Cha Cha Cha (1974), which stemmed from artistic networks, to reveal that New York was a much more cosmopolitan art scene than is usually presented in historiography. This chapter is followed by Victoria Souliman's analysis of Australian artists' expatriatism in the 1920s. Australian artists in the London art scene often felt ostracised in Britain as well as in Australia. Souliman thus proposes a singular case study of in-betweenness within the geographical sphere of the British Empire. Then comes Susan Waller's study of Agostina Segatori, an Italian model in Paris. Waller analyses the adjustment of an Italian artistic community - and especially models - in nineteenth-century Paris. The debates on Italian immigration, cultural differences and ideals of modernity conflicted with the interest of Parisian artists for Italian models. She thus unveils the construction of Italianicity in the nineteenth-century context of transnational artistic experiences. David Bell's chapter concludes this section with an examination of the in-betweenness of Japanese-style gardens in Oregon, USA, and the processes of alienation, and dispossession of Nikkei Japanese American communities during the twentieth century. This study offers a fresh perspective on conceptions of cultural and intercultural identity set in spatiotemporal movements. An innovative aspect of this section is that it shifts the focus away from the 
individual to the social aspects of art, i.e. from individual artistic practices to understudied artistic communities in Western metropoles. In doing so, the authors disclose some overlooked roots of identity politics in the art world, and how artists have, from early on, challenged national perceptions and narratives of art.

Finally, the concluding section is dedicated to the question of positionality mapping the researcher's identity - with the goal of stepping away from the neutrality of academic observers and revealing the contributors' personal experience of the interplay between art and migration. It starts with an interview with Leslie Ureña, associate curator of photographs at the Smithsonian's National Portrait Gallery. She describes the integration of foreign artists in the National Gallery, which focuses on American history but also includes non-Americans who have made a significant contribution to American history. She also evokes photography's power to represent migration both positively and negatively, as well as the diversity of migration experiences against fixed homogenous perceptions of migration. This chapter is followed by a conclusion on the notion of positionality which includes a note from all contributors as well as both editors to unveil their personal experience of migration and involvement in art and migration.

The following chapters show that art, and its mediation of multifaceted cultural viewpoints, conveys experiences of migration that resonate worldwide, and offers a powerful and continuous counterpoint to specific events of migration that have emerged at particular historical moments and have been portrayed as singularly other and destructive. Art and migration challenges the dichotomy between migrant and non-migrant art by reflecting on art's power to transcend politically constructed borders. By replacing the neatly defined and ultimately sterile border lines with the myriad lines of artistic creation, art replaces normative borders with subjective ones. By creating and feeding cultural currents that make borders pliable, art highlights that the political attempts at containment through borders are inoperative. Art has indeed constantly created points of encounter and convergence between individuals, places, and objects. It serves as a cultural crossroads, which challenges normative borders' stillness and propounds transnational identities, social intersections, and the deployment of multiple reference points. As such, it is a collective response to and effect of migration, the mediation process of artistic creation having long undermined the construct of migration 'crises' episodically deployed for strategic purposes. These political attempts reinforce the idea that globalisation is a profound and recent cultural shift that reverses centuries of cultural fixity and homogeneity - a narrative that art historians have long been engaged in revisioning, in terms and with methodologies shared by the social sciences, busy elaborating an histoire croisée of the circulation and production of knowledge (Werner and Zimmermann, 2003). 
Notes

1 A Fiction of Authenticity: Contemporary Africa Abroad is the title of the exhibition of African and African diaspora artists organised by Shannon Fitzgerald and Tumelo Mosaka for the Contemporary Art Museum St Louis, 20 September, 2003-3 January, 2004.

2 Some of the more critically acclaimed salvage of migrant objects involved fundraising, and use and transformation of the objects rather than installation exhibitions, such as the works of Anish Kapoor, Rachel Whiteread, Sean Scully, Julian Opie, and Jeremy Deller using crayons salvaged from the Calais Jungle for the Multicolor March 2019 exhibition by the refugee charity Migrate Art. www.phillips.com/article/42168298/in-conversation-with-simon-butler-of-migrate-art? Accessed 1 May 2020.

3 One Flew over the Void (Bala Perdida) is a 2005 video of a parade organised by Javier Téllez in Las Playas, on the border of Tijuana and San Diego ending with a human cannonball being shot over the border into the United States (Solomon 2005).

\section{References}

Ambrosini, M., M. Cinalli, and D. Jacobson (2020) Migration, Borders and Citizenship: Between Policy and Public Spheres (Cham: Palgrave Macmillan).

An, S.K. and K.K. Gower (2009) 'How do the News Media Frame Crises? A Content Analysis of Crisis News Coverage', Public Relations Review, 35:2, 107-112.

Anderson, B. (1991) Imagined Communities: Reflections on the Origin and Spread of Nationalism (London: Verso).

Antoni, J. and M. Hatoum (1998) 'Interview with Mona Hatoum', BOMB, 63, 54-61.

Anzaldúa, G. (2007) Borderlands/La Frontera: The New Mestiza (San Francisco: Ant Lute).

Baetens, J.D. and D. Lyna (2019) 'Towards an International History of the NineteenthCentury Art Trade, in J.D. Baetens and D. Lyna (eds), Art Crossing Borders (Leiden: Brill, 2019), 1-14.

Belloni, M. (2019) 'When the Phone Stops Ringing: On the Meanings and Causes of Disruptions in Communication between Eritrean Refugees and Their Families Back Home'. Global Networks. https://onlinelibrary.wiley.com/doi/abs/10.1111/glob.12230. Accessed 5 March 2019.

Berggren, E. (2019) 'Representation, Victimization or Identification: Negotiation Power and Powerlessness in Art on Migration', Journal of Mediterranean Knowledge$J M K, 4: 2,113-136$.

Boeva, A. (14 December 2016) 'Discursive Construction of Refugees, Migrants and Asylum Seekers in British and American News Sources', Procedia: Social and Behavioral Sciences, 236, 53-58.

Boin, A. (2004) 'Lessons from Crisis Research', International Studies Review, 6:1, 165. 
Boin, A., P. 't Hart, and A. McConnell (2009) 'Crisis Exploitation: Political and Policy Impacts of Framing Contests', Journal of European Public Policy, 16:1, 81-106.

Bruneau, M. (2010) 'Diasporas, Transnational Spaces and Communities', in R. Bauböck and T. Faist (eds), Diaspora and Transnationalism: Concepts, Theories and Methods (Amsterdam: Amsterdam University Press), 35-49.

Bydler, C. (2004) The Global Art World Inc.: On The Globalization of Contemporary Art (Uppsala: Uppsala University).

Canny, Nicholas P. (2014) Europeans on the Move: Studies on European Migration, 1500-180o (Oxford: Oxford University Press).

Chakrabarty, D. (200o) Provincializing Europe (Princeton, NJ: Princeton University Press).

Chang, A. (2009) Envisioning Diaspora: Asian American Visual Arts. From Godzilla, Godzookie, to the Barnstormers (Beijing: Timezone 8).

Chikukwa, R. (2016) Kabbo ka Muwala (The Girl's Basket): Migration and Mobility in Contemporary Art in Southern and Eastern Africa (Berlin: Germany Revolver Publishing).

Chong, H. (2006) 'Video Interview', in H. Abbas, C. Dellbrügge, and R. Moll (eds), Artist Migration Berlin (Heidelberg: Kehrer), 32-35.

Chubb, E. (2015) 'Differential Treatment: Migration in the Work of Yto Barrada and Bouchra Khalili', Journal of Arabic Literature, 46, 268-295.

Chubb, E. (2016) 'Small Boats, Slave Ship; or, Isaac Julien and the Beauty of Implied Catastrophe', Art Journal, 75:1, 24-43.

Cisneros, J.D. (2008), 'Contaminated Communities: The Metaphor of "Immigrant as Pollutant” in Media Representations of Immigration', Rhetoric \& Public Affairs, 11:4, 569-601.

Cooks, B.R. (2011) African Americans and the American Art Museum (Amherst, MA: University of Massachusetts Press).

Danko, D. (2018) 'Artivism and the Spirit of Avant-Garde Art', in V.D. Alexander, S. Hägg, S. Häyrynen, and E. Sevänen (eds), Art and the Challenge of Markets: From Commodification of Art to Artistic Critiques of Capitalism, Vol. 2 (Cham: Palgrave Macmillan), 235-261.

De Genova, N. (2017a) 'The "Migrant Crisis" as Racial Crisis: Do Black Lives Matter in Europe?' Ethnic and Racial Studies, 41:10, 1-18.

De Genova, N. (ed.) (2017b) The Borders of 'Europe': Autonomy of Migration, Tactics of Bordering (Durham, NC and London: Duke University Press).

Del Giudice, L. (2014) Sabato Rodia's Towers in Watts: Art, Migrations, Development (New York: Fordham University Press).

Demos, T.J. (2013a) Migrant Image: The Art and Politics of Documentary during Global Crisis (Durham, NC: Duke University Press).

Demos, T.J. (2013b) Return to the Postcolony: Spectres of Colonialism in Contemporary Art (Berlin: Sternberg Press).

Demos, T.J. (2017) 'Charting a Course: Exile, Diaspora, Nomads, Refugees, A Genealogy of Art and Migration', in M. Gioni, and M. Brambilla (eds), The Restless Earth: [exhibition, Triennale di Milano, 28.04-20.08.2017] (Milano: Electa), 18-26. 
DiMaggio, P. and P. Fernandez-Kelly (2010) Art in the Lives of Immigrant Communities in the United States (New Brunswick, NJ: Rutgers University Press).

Dulguerova, E. (2017) 'Thinking with Large-Scale Exhibitions about Space, History, and Art', Critique d'Art, 49, 47-55.

Fauri, F. (ed.) (2015) The History of Migration in Europe: Perspectives from Economics, Politics and Sociology (Abingdon and New York: Routledge).

Floyd, K.M. (2017) 'The Museum Exhibited: Documenta and the Museum Fridericianum, in Eva-Maria Troelenberg and Melania Savino (eds), Images of the Art Museum: Connecting Gaze and Discourse in the History of Museology Contact Zones, Vol. 3 (Berlin and Boston: De Gruyter), 65-90.

Georgiou, M. (2012) 'Introduction: Gender, Migration and the Media', Ethnic and Racial Studies, 35:5, 791-799.

Green, C. and A. Gardner (2016) Biennials, Triennials, and Documenta: The Exhibitions that Created Contemporary Art (Malden: Wiley-Blackwell).

Greenblatt, S. (2010) Cultural Mobility: A Manifesto (Cambridge: Cambridge University Press).

Greussing, E. and H.G. Boomgaarden (2017) 'Shifting the Refugee Narrative? An Automated Frame Analysis of Europe's 2015 Refugee Crisis', Journal of Ethnic and Migration Studies, 43:11, 1749-1774.

Guha, R. (1998) 'The Migrant's Time', Postcolonial Studies, 1:2, 155-160.

Hassan, S.M. and O. Oguibe (2001) 'Introduction', in S.M. Hassan, O. Oguibe, Siemon Allen, and Forum for African Arts (eds), Authentic/Ex-centric: Conceptualism in Contemporary African Art (Ithaca, NY: Forum For African Arts), 10-24.

Hicks, D. and S. Mallet (2019) Lande: The Calais Jungle and Beyond (Bristol: Bristol University Press).

Hier, S.P. and J.L. Greenberg (2002) 'Constructing a Discursive Crisis: Risk, Problematization and Illegal Chinese in Canada', The Journal of Ethnic and Racial Studies, 25:3, 490-513.

Hoerder, D. (2019) 'Migrations and Macro-Regions in Times of Crises: Long-Term Historiographic Perspectives', in C. Menjivar, M. Ruiz, and I. Ness (eds), The Handbook of Migration Crises (New York and Oxford: Oxford University Press), 21-36.

Holmes, S.M. and H. Castañeda (2016) 'Representing the "European Refugee Crisis" in Germany and Beyond: Deservingness and Difference, Life and Death', American Ethnologist, 43:1, 12-24.

Jameson, F. (2010) 'The National Situation', in J. Elkins, Z. Valiavicharska, and A. Kim (eds), Art and Globalization, Volume 1 of Stone Art Theory Institutes (Philadelphia, PA: The University of Pennsylvania Press), 13-22.

Jones, C.A. (2016) The Global Work of Art: World's Fair, Biennials, and the Aesthetics of Experience (Chicago, IL: University of Chicago Press).

Kaplan, C. (1996) Question of Travel, Post-Modernistic Discourse of Displacement (Durham, NC: Duke University Press).

King, A.D. (1990) Global Cities: Post-Imperialism and the Internationalization of London (London: Routledge).

Knappett, C. (2005) Thinking Through Material Culture: An Interdisciplinary Perspective (Philadelphia, PA: The University of Pennsylvania Press). 
Lindley, A. (2014) Crisis and Migration: Critical Perspectives (London: Routledge).

Lonetree, A. (2012) Decolonizing Museums: Representing Native America in National and Tribal Museums (Chapel Hill, NC: University of North Carolina Press).

Lucassen, L. (2015) The Immigrant Threat: The Integration of Old and New Migrants in Western Europe since 1850 (Chicago and Urbana, IL: The University of Illinois Press).

Luhmann, N. (2000) Art as a Social System (Stanford, CA: Stanford University Press).

Lum, K. (2020) Everything is Relevant: Writings on Art and Life, 1991-2018 (Montreal: Concordia University Press).

Macel, C. (2017) Viva Arte Viva: Biennale Arte 2017: la Biennale di Venezia 57 (Venice: Venice Biennale).

MacKenzie, J. (1995) Orientalism: History, Theory and the Arts (Manchester: Manchester University Press).

MacKenzie, J. (2009) Museums and Empire: Natural History, Human Cultures and Colonial Identities (Manchester: Manchester University Press).

Mainwaring, C. (2012) 'Constructing a Crisis: The Role of Immigration Detention in Malta', Population, Space and Place, 18:6, 687-70o.

Mathur, S. (ed.) (2011) The Migrant's Time: Rethinking Art History and Diaspora (Williamson: Sterline and Francis Clark Institute; New Haven, CT: Yale University Press).

McAdam, J. (2014) 'Conceptualizing “Crisis Migration”: A Theoretical Perspective', in S.F. Martin, S. Weerasinghe, and A. Taylor (eds), Humanitarian Crisis and Migration: Causes, Consequences and Responses (London: Routledge), 28-49.

Mercer, K. (2008) Exiles, Diasporas \& Strangers (Cambridge, MA and London: MIT Press).

Meskimmon, M. (2011) Contemporary Art and the Cosmopolitan Imagination (London: Routledge).

Meyer, A. and B. Savoy (eds) (2014) The Museum is Open: Towards a Transnational History of Museums 1750-1940 (Berlin: De Gruyter).

Mezzofiore, G. (2019), “Drowning Hands” Guerrilla Artwork Protests Italy's Hard Line on Migrants', CNN, 7 February. https://edition.cnn.com/style/article/artinstallation-drowning-hands-italy-scli-intl/index.html?fbclid=IwARoYpRFXRY 8aAtwosKSoWAT6cUv9Q_PflX2CHApuk4Psom_A-NTJojoC9O4. Accessed 10 March 2019.

Mosland, S.P., A.R. Petersen, and M. Schramm (2015) The Culture of Migration: Politics, Aesthetics and Histories (London and New York: I.B. Tauris).

Mufti, A.R. (2011) 'Zarina Hashmi and the Arts of Dispossession', in S. Mathur (ed.), The Migrant's Time: Rethinking Art History and Diaspora (Williamson: Sterline and Francis Clark Institute; New Haven, CT: Yale University Press), 174-195.

Mukherji, P.D. (2014) 'Whither Art History in a Globalizing World', The Art Bulletin, 96:2, 151-155.

Ojala-Fulwood, M. (2018) Migration and Multi-Ethnic Communities: Mobile People from the Late Middle Ages to the Present (Berlin: De Gruyter).

Ong, A. (2017) 'The Successes and Failures of Documenta in Athens' Apollo: The International Art Magazine [online magazine], 16 May. www.apollo-magazine.com/ the-successes-and-failures-of-documenta-in-athens. Accessed 10 March 2019. 
Petersen, A.R. (2017) Migration into Art: Transcultural Identities and Art-Making in a Globalised World (Manchester: Manchester University Press).

Quemin, A. (2004) 'The Illusion of the Elimination of Borders in the Contemporary Art World: The Role of the Different Countries in the "Era of Globalization and Métissage", in J. Bakoš (ed.), Artwork through the Market (Nadácia: Centrum Súčasného Umenia), 275-301.

Rancière, J. (2003) 'Politics and Aesthetics: An interview', Angelaki, 8:2, 191-211.

Reilly, M., and L.R. Lippard (2018) Curatorial Activism: Towards an Ethic of Curating (London: Thames \& Hudson).

Ríos, A. (2015) A Small Story About the Sky (Washington, DC: Copper Canyon Press)

Ruz, C. (2015) 'The Battle over the Words used to Describe Migrants', BBC News Magazine, 28 August. www.bbc.com/news/magazine-34061097. Accessed 10 December 2019.

Said, E.W. (1983) The World, the Text and the Critic (Cambridge, MA: Harvard University Press).

Sassen, S. (2006) Territory, Authority, Rights: From Medieval to Global Assemblages (Princeton, NJ: Princeton University Press).

Schuetze C. (2015) 'Narrative Fortresses: Crisis Narratives and Conflict in the Conservation of Mount Gorongosa, Mozambique', Conservation \& Society, 13:2, 141-153.

Sheren, I.N. (2015) Portable Borders: Performance Art and Politics on the U.S. Frontera since 1984 (Austin, TX: University of Texas Press).

Solomon R. (2005) One Flew over the Void (Bala Perdida) (Guggenheim Museum, 2014:52).

Sontag, K. (2018) Mobile Entrepreneurs: An Ethnographic Study of the Migration of the Highly Skilled (Toronto: Verlag Barbara Budrich).

Steger, M. (2008) The Rise of the Global Imaginary: Political Ideologies from the French Revolution to the Global War on Terror (Oxford: Oxford University Press).

Szymczyk, A. (2015) 'Editors' Letter', South as a State of Mind: Documenta 14 vol. 1. www.documenta14.de/en/south/12_editors_letter. Accessed 3 March 2019.

Tacoli, C. (2009) 'Crisis or Adaptation? Migration and Climate Change in a Context of High Mobility', Environment and Urbanization, 21:2, 513-525.

Tilley, C. (2001) 'Ethnography and Material Culture', in P.A. Atkinson, A. Coffey, S. Delamont, J. Lofland and L. lofland (eds), Handbook of Ethnography (London: Sage), 258-272.

Valiavicharska, Z. (2010) 'Second Introduction', in J. Elkins, Z. Valiavicharska, and A. Kim (eds), Art and Globalization, Volume 1 of Stone Art Theory Institutes (Philadelphia, PA: The University of Pennsylvania Press), 5-7.

Van Brummelen, L. (2005) The Formal Trajectory (Berlin: Pro-qm). www.vanbrummelendehaan.nl/Van_Brummelen_\%26_De_Haan/The_Formal_Trajectory_en_ne_2. html\#O. Accessed 3 March 2019.

Van der Meer, T., P. Verhoeven, H. Beentjes, and R. Vliegenthart (2014), 'When Frames Align: The Interplay between PR, News Media, and the Public in times of Crisis', Public Relations Review, 40:5, 751-761.

Velthuis, O. and S. Baia Curioni (2015) 'Making Markets Global', in O. Velthuis and 
S. Baia Curioni (eds), Cosmopolitan Canvases: The Globalization of Markets for Contemporary Art (Oxford: Oxford University Press), 1-3o.

Vermeylen, F. (2015) 'The India Art Fair and the Market for Visual Arts in the Global South, in O. Velthuis and S. Baia Curioni (eds), Cosmopolitan Canvases: The Globalization of Markets for Contemporary Art (Oxford: Oxford University Press), 31-54.

Wagner, K., J. David, and M. Klemenčič (2017) Artists and Migration, 1400-1850 (Newcastle upon Tyne: Cambridge Scholars).

Waller, S., and K.L. Carter (2015) Foreign Artists and Communities in Modern Paris, 1870-1914: Strangers in Paradise (Aldershot: Ashgate).

Weiner, M. (1995) The Global Migration Crisis: Challenge to States and to Human Rights (New York: Harper Collins).

Werner, M. and B. Zimmermann (2003) 'Penser l'Histoire Croisée: entre Empirie et Réflexivité' Annales. Histoire, Sciences Sociales, 58:1, 7-36.

Wrapson, L., V. Sutcliffe, and S. Woodcock (2019) Migrants: Art, Artists, Materials and Ideas Crossing Borders (London: Archetype).

While, A. (2003) 'Locating Art Worlds: London and the Making of Young British Art', Area, 35:3, 251-263.

Whitehead, C., K. Lloyd, S. Eckersley, and R. Mason (2017) Museums, Migration and Identity in Europe: Peoples, Places and Identities (London: Routledge).

Yanow, D. (2014) 'I Am Not a Camera: On Visual Politics and Method. A Response to Roy Germano', Perspectives on Politics, 12:3, 680-683. 
Bénédicte Miyamoto and Marie Ruiz - 9781526149718 Downloaded from manchesterhive.com at $04 / 26 / 2023$ 12:45:35PM via free access 